\title{
Article \\ Party Competition Structure and Legislative Productivity of Local Councils: From the 4th to 6th Local Councils in Korea
}

\author{
Sung Eun Jung ${ }^{1}$ and Yongmin Kim $^{2, * \mathbb{D}}$ \\ 1 Department of Political Science, College of Social Science Konkuk University, Seoul 05029, Korea; \\ belarbre@konkuk.ac.kr \\ 2 KU China Institute, Konkuk University, Seoul 05029, Korea \\ * Correspondence: kym7224@konkuk.ac.kr
}

Citation: Jung, Sung Eun, and Yongmin Kim. 2022. Party Competition Structure and Legislative Productivity of Local Councils: From the 4th to 6th Local Councils in Korea. Social Sciences 11 94. https://doi.org/10.3390/socsci 11030094

Academic Editor: Reimut Zohlnhöfer

Received: 29 December 2021

Accepted: 20 February 2022

Published: 23 February 2022

Publisher's Note: MDPI stays neutral with regard to jurisdictional claims in published maps and institutional affiliations.

Copyright: (C) 2022 by the authors. Licensee MDPI, Basel, Switzerland. This article is an open access article distributed under the terms and conditions of the Creative Commons Attribution (CC BY) license (https:// creativecommons.org/licenses/by/ $4.0 /)$.

\begin{abstract}
The Korean local autonomy system has a unique feature in that it grants councils, mayors, and governors the right to submit bills. Because of Korea's extensive experience with authoritarianism, the relative legislative productivity of the assembly with respect to the head of the group - that is, the person who has the legislative initiative-has become an evaluation criterion for the activities of local councils in Korea. In this study, we address the question of why the relative legislative productivity of individual councils appears to be the cause of problematic awareness in situations where the legal and institutional conditions-for example, the organization and function of local councils, operating methods, and support systems - are very similar. Accordingly, regarding the 4th to 6th parliamentary period (2006-2018) of 15 parliaments, panel data analysis was performed to understand how the structure of party competition between the heads of the group and parliament and the structure of party competition within the assembly affects the relative legislative productivity of the assembly from a macro perspective. It was found that the relative legislative productivity of the parliament for mayors increases when there is a divided government rather than unified one and when the seat share of the first party in parliament increases. However, it was also found that the greater the difference in seat share between the first party in parliament and the second party in parliament, the higher the index of party concentration in parliament and the lower the relative legislative productivity of parliament. In Korea's political reality, it was confirmed that the political structure of a divided government at the local level does not necessarily lead to a decrease in legislative productivity. The significance of this study is that these ideas were verified.
\end{abstract}

Keywords: local council; local government; legislative productivity; party competition; metropolitan scale

\section{Introduction}

The local autonomy system, which started with the founding of the Republic of Korea in 1945, entered a dormant period under the authoritarian regime (1961-1987) but then went through democratization in 1987, which became a turning point for its revival. Since the first local elections in 1995, the true meaning of local government and local councils was defined through the first nationwide local elections in which residents directly elected the head of the local government and local council members at the same time. Since 1998, local elections have been readjusted to a four-year cycle, and until the time of writing this paper, the seventh local council and local government have been formed. The Korean local autonomy system has a unique feature in that it grants both parliament and the heads of local governments the right to submit bills. In other words, the legislative power is not exclusive to parliament, and the executive's right to submit bills is recognized. To pull "the cart" of the local autonomy system, the two wheels-the heads of the local government and local council-are required to perform checks and balances on each other. However, because of the experience of authoritarianism, a large bureaucratic organization took the lead in setting and executing policies, and a political environment in which the executive, 
not parliament, exercised the legislative initiative has continued for a long time. It is not strange, then that executive legislation far outweighs parliamentary legislation.

The legislative productivity of parliament can be defined as the total amount of policy changes made by parliament. Under representative democracy, a key activity of parliament is to reconcile the various interests and conflicts in society and create legislation by projecting such coordinated intentions into the legislative process. Therefore, legislative productivity is one of the most important indicators for evaluating parliament.

Using a box plot, Figure 1 visualizes the legislative trend of the 15 local councils in Korea from the 1 st to 6 th parliaments. The median value indicated by the straight line inside the box gradually increases and the overall position of the box rises, which indicates that the overall rate of proposals in parliament has increased over time. In the 1st to 3rd (1995-2006) parliaments, the relative productivity of legislation regarding the executive was only $10-20 \%$ of all bills. In other words, the executive, not the parliament, led legislation. Although legislation is the most important function of parliament, the evaluation of the legislative activities of local councils was not good because of low legislative productivity. The structural and environmental limitations of party politics, in which a specific party monopolizes the head of the local government and parliament, were pointed out as major problems because of strong regionalism, as were the lack of qualifications and weak professionalism of local councilors resulting from the inadequacy of the system. However, starting from the fourth parliament, the rate of legislative proposals rapidly increased, and during the fifth term of the local parliaments, several parliaments with more than $50 \%$ of the total legislative rate began to be observed. Finally, the local council began to take the lead in legislation.

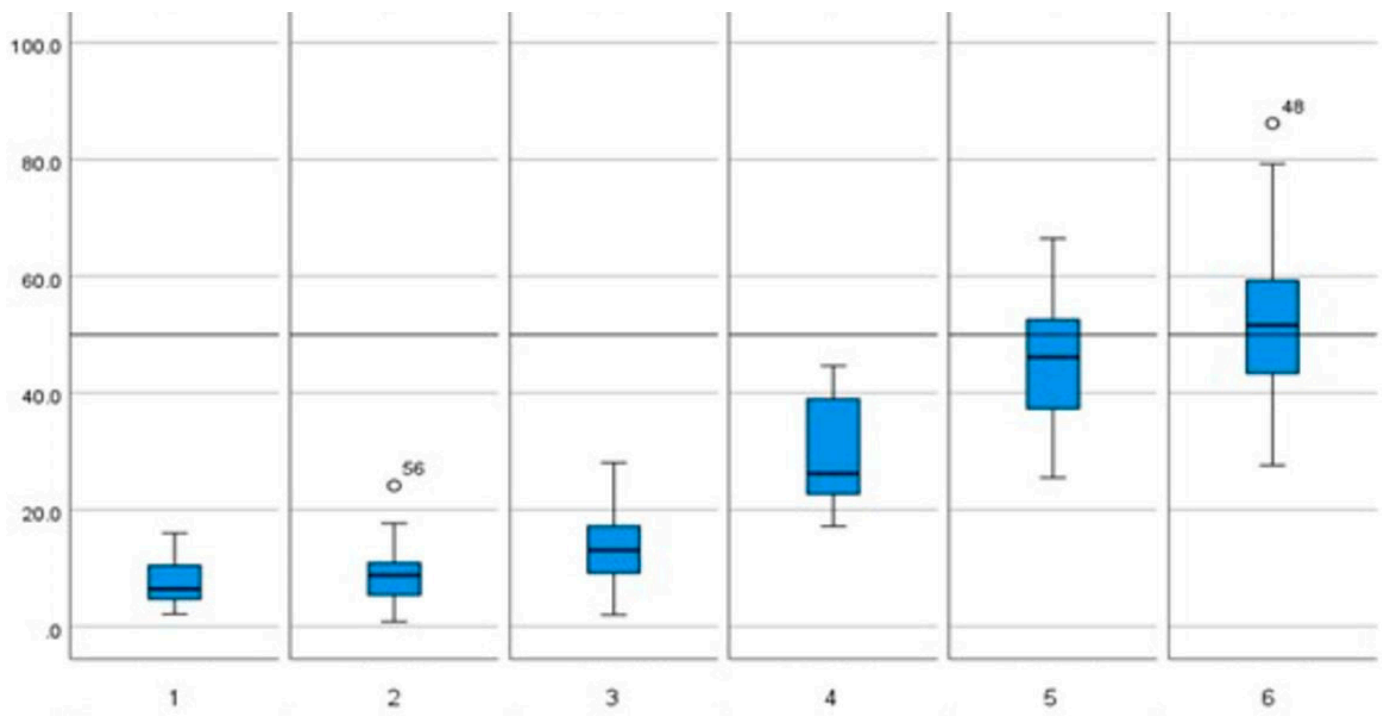

Figure 1. Proposal rate of local councils (total trend). Image edited.

What changes to local Korean councils have occurred?

The biggest cause can be found in the laws and institutional changes in the local autonomy system. The internal and external environment and system of local councils, as stipulated in the "Local Autonomy Act", changed significantly in 2006 before the fourth local election. Through the revision of the "Local Autonomy Act" (Law No. 7935), various systems were introduced and implemented to increase the autonomy and efficiency of local councils, e.g., the operation of the session of local councils and autonomy of the establishment of standing committees, an increase in expert members to local council committees, and an expansion of the expert committee system. Above all, a paid system was created and implemented for local council members who had previously held unpaid and honorary positions; this represented an opportunity to greatly increase the professionalism 
of local councilors. In this manner, the weaknesses of the local council system were greatly addressed.

Another difference can be seen in Figure 1 between the period from the 1st to 3rd parliaments and the period from the 4th to 6th parliaments. The upper and lower lengths of the box are significantly longer from the 4th to 6th councils than from the 1st to 3rd councils. This means that the difference between the minimum and maximum values of each local council's proposal rate by period has been increasing. In other words, there has been a great difference in the rate of proposals in each local council. Some local councils have secured the legislative initiative since the 5 th term of councils and have a proposal rate approaching $80 \%$, while some are still at less than $30 \%$. The research question of the current study arises from the question of why the legislative productivity of individual councils has greatly differed in a situation where the legal and institutional conditions-such as the organization and function, operation method, and support system of local councils-have been made similar through the revision of the Local Autonomy Act. When it comes to local autonomy in Korea, where the government's legislative authority is guaranteed, the power structure between the heads of the local government and the council and the competitive structure within the local council are important factors that affect the legislative productivity of the council.

The legislative process cannot be separated from those political processes that transpire in a governance system. Although the checks-and-balances mechanism is expected to bolster a strong government through monitoring from the legislative body, history has indicated that the political process operates in the interests of political camps at the expense of public interests (Azlansyah et al. 2020).

Based on the specificity of the Korean local political system, questions may arise regarding what affects the performance of local councils and the legislative process. Related to this research question, we formulated a hypothesis for this study: party competition, such as a divided government, affects the performance of local councils in the legislation process. The current study was aimed to analyze the legislative productivity of local councils that are affected by the political situation under party competition. Additionally, we intended to clarify the cause from a macroscopic perspective because it is not a microscopic factor (such as the individual attributes of lawmakers) but a structure of party competition within the local councils and between mayors and local councils.

\section{Literature Review: Party Competition and Legislative Productivity}

Measuring parliament's productivity is a legislative matter and the primary task of parliament. Legislative productivity can be divided into input-side productivity and output-side productivity, depending on which part of the legislative process is the focus. In terms of input, legislative productivity focuses on legislative proposals in which those members representing the people, who are voters, put the will of the voters and supporters into parliament. Because the number of bills each legislator has submitted is important in terms of not only democracy but also representativeness and integrity, it has been used as an important measure of legislative productivity (Matthews 1960; Olson and Nonidez 1972).

Members of local councils can perform the function of publicizing the opinions of voters and supporters within the parliament-regardless of the content of the proposed bill or whether it is passed or not-and can suggest social problems or problem-solving methods that the administration has not considered. Therefore, the legislative proposal of a bill is meaningful just because it is introduced in the legislative process, regardless of it passing. However, the legislative productivity of the input side has a limitation in that it does not cover the entire legislative process. This is because the proposed bill may be changed during the legislative process and thus be amended or changed to a state different than what was originally intended. In this context, it is necessary to consider legislative productivity in terms of output together with input. Legislative productivity on the output side is different from that on the input side, which focuses on the proposal itself but measures legislative productivity via the number of passages of legislation or the ratio 
of output to input (Cox and Terry 2008). In terms of output, legislative productivity can be viewed as an approach from a parliamentary-centered decision-making point of view, so it can be a more effective indicator when trying to improve productivity at the parliamentary level.

In addition, a bill passed through the legislative process, such as committee deliberation and resolution, can be regarded as guaranteeing a minimum quality level, so if the legislative productivity on the output side is also considered, the limitation of the legislative productivity on the input side can be supplemented. Various studies have been conducted on the factors affecting legislative productivity. In particular, traditional legislative productivity studies have focused on the personal attributes of legislative actors (Matthews 1960; Fenno 1973; Schiller 1995). These studies presuppose that individual characteristics, such as individual levels of knowledge and education, affect legislative productivity, thus leading to efforts to identify the personal attributes of highly legislative members to achieve the goal of strengthening legislative productivity (Matthews 1960; Ellickson 1992; Volden and Wiseman 2014). Research has also been conducted on the necessity and expansion of parliamentary support organizations required for the legislative activities of lawmakers (McCubbins and Sullivan 1987; Thomas 1995). If legislative power is exclusive to parliament, it would be easy to achieve the goal of strengthening the absolute legislative productivity of parliament by identifying the microscopic attributes of each member who has high legislative productivity.

However, the current study was focused on the relative legislative productivity of parliament with respect to the head of the local government, not on the absolute legislative productivity of parliament. This is because the local autonomy system of Korea recognizes not only the legislative power of parliament but also the legislative power of the head of local government. Therefore, it was necessary to closely examine the incentives that affect the legislative productivity of parliament relative to the mayor or governor-namely, the parliamentary versus local government head-and the political party competition structure within parliament. Party competition can be divided between parliament and the local government head and within an assembly itself. The authors of a representative study on the structure of party competition between parliament and the mayor/governor discussed unified government/divided government; according to the most general definitions, a divided government is when the executive and legislative branches divide power because the local government leader belongs to a different party than the parliamentary majority and a unified government is when the local government leader belongs to the same party as the majority and there is a parliamentary majority (Fiorina 1996).

In the literature on the effect of divided government on legislative productivity, positive and negative theories have conflicted, but in general, the negative theory that a divided government is relatively inefficient compared to a unified government has prevailed. From a legislative point of view, a divided government divides the legislative power between parties with different political ideologies and interests, so conflicts between the parties are unavoidable. In the end, compared to a unified government, the divided government causes the paralysis of political operations because of conflicts between parliament and the executive branch, that is, legislative deadlock, and this deepens political irresponsibility and inefficiency (Sundquist 1988; Kelly 1993; Edwards et al. 1997). Mayhew raised an objection based on empirical research on the negative perception of a divided government. According to Mayhew $(1991,2005)$, whether a government is divided or unified is irrelevant to the legislative productivity of parliaments. Jones (2005) argued that if the degree of party polarization is high and no party has secured an absolute majority of seats, the possibility of a legislative deadlock in a unified government is as high as that of a divided government. He further argued that the legislative activity of parliament and passing major bills tend to be found more often during a divided government period.

Binder (2003) reported that both the 103rd Congress during the Clinton administration and the 109th Congress during the Bush administration formed a unified government, but the legislative efficiency during the unified government period was not higher than 
that during the divided government period. Most empirical studies have focused on lawmaking at the national level using a measure of legislative output as the dependent variable. Among the few studies on a divided government at the local government level is Rogers' (2005) study of U.S. state governments, in which it was reported that legislation was reduced by about $30 \%$ when parliament was divided but the divided structure of parliament and the executive had no effect on legislation. Kirkland and Phillips (2018) focused on legislative delays at the local level, examining whether a divided government threatens the ability of lawmakers to meet critical deadlines. Specifically, they considered whether the presence of a divided government increased the probability that lawmakers would adopt a late budget. Their RDD (regression discontinuity design) approach provided convincing evidence that a divided government was the cause of the delay. They also showed that a divided government was more likely to lead to delays when the personal and political costs that a stalemate imposes on politicians were low. Their findings could help explain Mayhew and others' arguments that a divided government does not necessarily reduce the passage of landmark legislation.

Wu (2009) and Wu and Huang (2007) conducted empirical studies based on a 2002 survey of local governments in Taiwan. The surveys were conducted at the local government level by dividing the distribution of the heads of local governments and political parties within parliament into six types. Looking at the results of the study more specifically, the types of government are as follows: (1) the Taiwan Chinese Nationalist Party unified government, (2) the Taiwan Chinese Nationalist Party divided government (the Taiwan Chinese Nationalist Party does not have a majority in parliament), (3) the Taiwan Chinese Nationalist Party divided government (the Taiwan Chinese Nationalist Party has a minority in parliament), (4) the Democratic Progressive Party divided government (the Taiwan Chinese Nationalist Party does not have a majority in parliament), (5) the Democratic Progressive Party divided government (the Taiwan Chinese Nationalist Party has a minority in parliament), and (6) the independent divided government (with an independent controlling the executive branch and the Taiwan Chinese Nationalist Party holding a minority of seats in parliament). Following a comparative analysis of all six types, such as the independent divided government (the head of an independent local government and the Taiwan Chinese Nationalist Party being minority parties in parliament), the results showed that the unified government had higher activity and citizen satisfaction than the divided government.

Azlansyah et al. (2020) observed the factors that impacted the performance of legislation in the Indonesian province of Aceh over from 2014 to 2018; the study indicated that the two major political parties in the region strongly competed within parliament, resulting in a political vacuum and unproductiveness. With ineffective communication between each other, the government and parliament did not optimally work to pass many bills in every analyzed one-year term. Ultimately, a divided government was found to lead to a vacuum or the unproductivity of elements of the provincial government.

Most Korean studies on the legislative productivity of local councils have dealt with divided governments as one of the many variables affecting the legislative activities of local councilors. Cross-sectional analysis has mainly been carried out in terms of the subject and time of analysis, and even when time series data have been used, analysis has been conducted for specific parliaments in many cases. The relationship between party competition structure and legislative productivity has also varied depending on which parliament was analyzed. When party competition intensifies because of the occurrence of a divided government, political confrontation and conflicts arise, stagnate politics, and create an administrative vacancy, thus resulting in lower parliamentary productivity (Kim 1997). On the other hand, some results (Lim 2000; Cho 2003; Park 2010) have indicated that political dynamism increases in the case of a divided government, leading to more active legislative activities and active checks on the legislative and executive sides. Other results have shown that the form of government does not have statistical significance in terms of legislative productivity and that statistical significance depends on the studied period and time (Jeong and Lee 2008). In a previous study dealing with the form of government and legislative 
productivity at the local government level, the results showed that members of the minority party were more active in checking the mayor belonging to the majority party, as well as the majority party itself, under the divided government structure (Park 2010), and results were similar with a divided government and a unified government. One study confirmed that rather than uniformly lowering legislative productivity, there may be differences depending on the divided government's operation method (Park and Choi 2016).

It can be seen that the authors of many previous studies have analyzed the differences in the political process and policy production between unified and divided governments by using the comparative or statistical analyses of several cases. Different results depending on each research method and subject have been reported, but it has been commonly suggested that the negative effects on the legislative productivity of parliament seen when there is too much competition or when an overwhelming party dominates with no real interest to compete are transformed into positively effects on legislative productivity when there is moderate competition. Therefore, the authors of the present study attempted to analyze how the competitive structure within and outside the local council affects the relative legislative productivity of the mayor or governor from the point of view of political power. By examining how the party competition structure acts as an incentive for the legislative productivity of parliament, the authors of the present study investigated whether appropriate competition can enhance legislative activity.

\section{Research Design}

The local autonomy system of Korea is a multitier system in which several local governments overlap within a single zone. Local governments based on the smallest area in direct contact with residents are called basic local governments, and local governments in a wider area located between the central government and basic local governments are called metropolitan governments. Local councils are also divided into basic local councils and metropolitan councils. Therefore, there are 226 basic local councils and 17 metropolitan councils in Korea. The spatial scope of the study was 15 of the 17 metropolitan councils, excluding the Sejong Council and the Jeju Council because their high autonomy is guaranteed by the special law and they have a very different administrative system from the general 15 metropolitan councils. The Sejong special self-governing city council is a single metropolitan government that does not have a basic local government as an administrative complex city in Korea. The Jeju special self-governing provincial council also does not have a basic local government under it, but many special cases are recognized for its organization, administration, and finances, such as having two administrative cities directly appointed by the governor. Above all, the Sejong and Jeju Councils were launched in 2012 and in 2006, respectively, so it was difficult to compare and analyze them within the same time range as the 15 metropolitan councils.

The time range was from July 2006 to June 2018. In other words, the scope of analysis was from the 4 th to 6 th councils, where simultaneous local elections were held nationwide and the heads of local governments and local councils were formed. We analyzed legislative activities from the 4th council, not from the 1st council, to conduct a more appropriate analysis of the reality of local autonomy in Korea. From the 1st to 3rd councils, local council members worked as unpaid and honorary councilors, and there was a strong tendency for local autonomy to be mainly operated by the heads of local governments. However, once the paid system of local council members began in the 4th council and was converted to a full-time and professional council, expertise and responsibility could be expected for various parliamentary activities, including legislative activities. Accordingly, the range for analysis was from the 4th council (2006-2010) to the 6th council (2014-2018). We conducted analyses by council terms, not by year, because of the special election system in Korea. The presidential election of the Republic of Korea, the national assembly elections, and the local elections are held separately, and each term of office is inconsistent. The parliamentary activities of local councils are greatly influenced by the cycle of other national elections and national politics. Therefore, rather than comparing the legislative productivity of the 
council by year, focusing on terms helped maintain data consistency. For these reasons, we conducted a synchronic analysis from the 4 th to 6 th parliaments of 15 metropolitan councils. Utilizing the data of the 15 metropolitan councils and the research design while considering the specificity of the Korean local autonomy system, we re-evaluated the hypothesis that party competition structure affects legislative performance.

\subsection{Hypothesis}

The following four hypotheses regarding the effect of the internal and external party competition structure on the legislative productivity of local councils were explored.

Hypothesis 1 (H1). There is a more positive effect on the legislative productivity of the local council for the mayor or governor when there is a divided government than when there is a unified government.

In Korea, in which the mayor, governor, and parliament hold legislative power, a divided government can be said to be a phenomenon in which different parties compete by dividing their legislative power. In a divided government, the majority of parliament is more enthusiastic about legislative activities because the incentive to compete with the mayor or governor or the party belonging to the mayor or governor increases. In a divided government, the parliamentary majority is more likely to realize their partisan interests. Therefore, under a divided government, this majority tries to submit and pass more bills to the council.

Hypothesis 2 (H2). The higher the seat share of the first party, the higher the legislative productivity of the local council.

The higher the proportion of members who share the same political interests in the council, the more actively the policy will of a specific party can be discussed. Greater incentives for majority lawmakers to work harder ultimately increase the legislative productivity of local councils for mayors or governors. This is because the results of local council activities can also be used as a basis for the re-election of members.

Hypothesis 3 (H3). Increases in the difference in seat share between the first and second parties negatively affect the legislative productivity of local councils.

Although the Korean party system is a two major-party system, there are cases in which a party with particularly overwhelming dominance exists in a specific region. Therefore, as the difference in seat share between the first and second parties increases, the influence of a strong regional party increases. In this case, actual incentives for competition are reduced, which has a negative impact on legislative productivity.

Hypothesis 4 (H4). Increases in the concentration of political parties in the local council negatively affect the legislative productivity of the local council.

The party concentration index of local councils is an indicator of the party competition structure that utilizes all the seat shares of the parties entering the local council. The degree of party concentration in Korean local councils is generally classified as a highly concentrated parliament - that is, a parliament with a low degree of competition. Because an increase in party concentration means a decrease in party competition, this is expected to have a slight negative impact on the legislative productivity of the local council.

\subsection{Variable}

3.2.1. Dependent Variables: Measuring Legislative Productivity in Local Councils

The dependent variable-legislative productivity — was measured in two ways. To measure the legislative productivity of the input side, the legislative proposal rate was 
set as the dependent variable and the legislative approval rate was set as the dependent variable in order to measure the output side of legislative productivity. We set the legislative proposal and approval rates as dependent variables in order to focus on legislative productivity relative to the mayor or governor rather than the legislative productivity of the parliament itself. In Korea, legislation is divided into parliamentary legislation and executive legislation based on the subject of the proposal. The first dependent variablethe proposal rate-was measured as the ratio of bills proposed by the local council out of the total number of proposed bills. Here, the number of bills proposed by the local council includes all bills proposed by local councils, such as those proposed by individual councilors, committees, and each committee chairperson and local council chairperson. The total number of bills proposed means the sum of the number of bills proposed by the local council and the number of bills submitted by the mayor or governor. The second dependent variable - the approval rate-was measured in the same way and refers to the ratio of bills passed by the local council (total approval of original bills and amendments) to the total number of bills passed. The framework of research analysis can be confirmed by Figure 2.

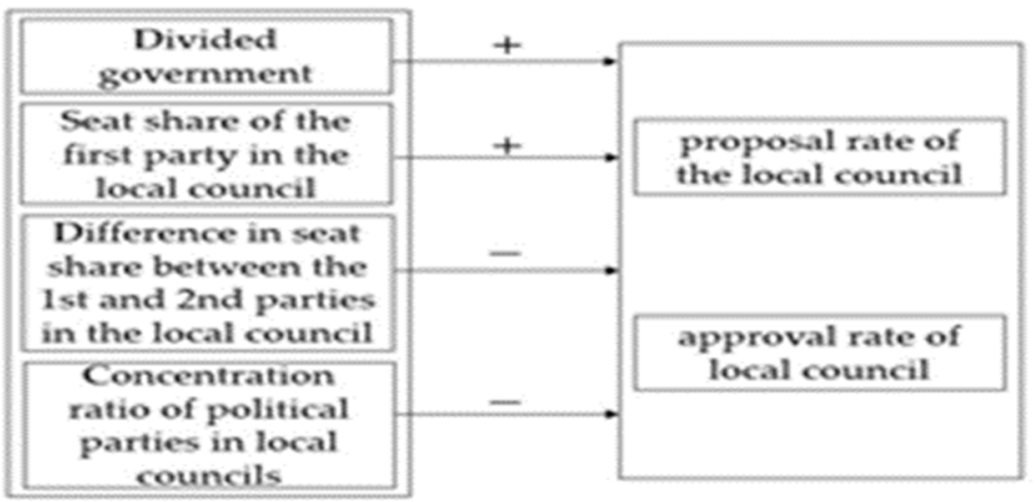

Figure 2. Analysis framework.

As shown in Figure 3, the legislative proposal and approval rates, which indicate changes, are summarized as time series data for each council to empirically verify the effect of party competition in local councils on securing legislative initiatives in local councils through panel data analysis.

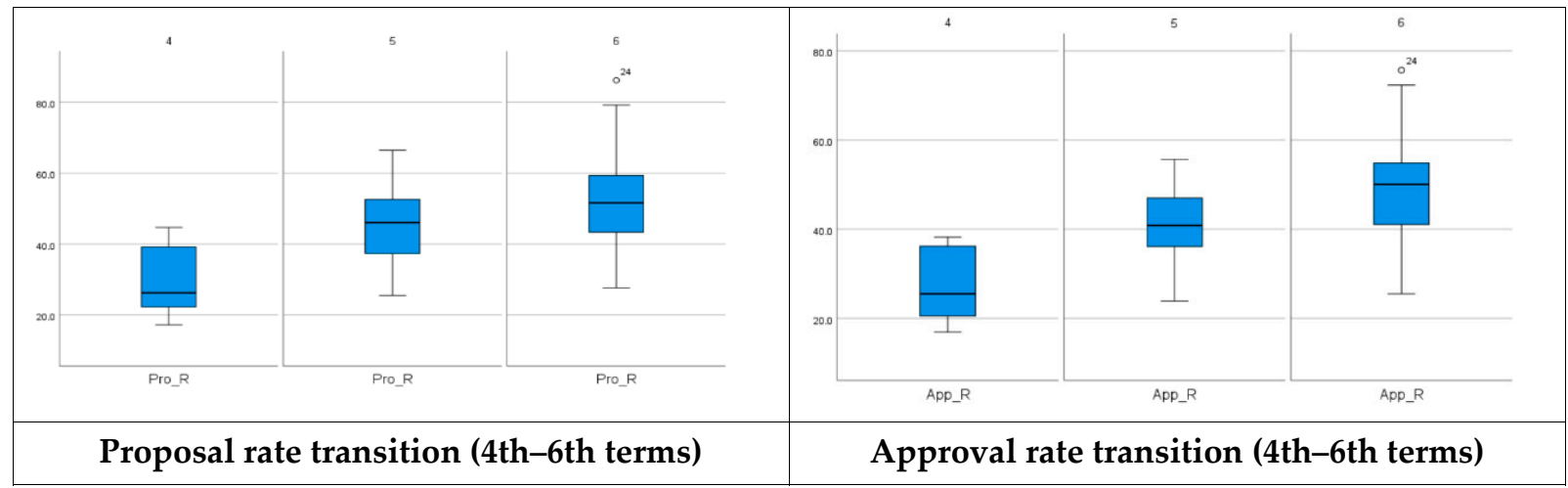

Figure 3. Proposal rate and approval rate transition of 15 local councils from the 4 th to 6 th terms.

\subsubsection{Explanatory Variables: Party Competition Structure}

The party competition structure was set as an independent variable, and it was divided into the party competition structure between the local council and the mayor or governor and the party competition structure within the local council. 
First, in the political party competition structure between the local council and the mayor or governor, the most important indicator is the form of local government, i.e., whether it is a unified or divided government. The form of government of 15 local councils formed through three local elections over the past 12 years is shown in Table 1 . In 15 metropolitan councils across the country, a divided government appeared in five areas (Seoul, Gyeonggi-do, Chungcheongnam-do, Gangwon-do, and Gyeongsangnam-do) in the 5 th assembly and four areas (Gyeonggi-do, Chungcheongnam-do, Chungcheongbuk-do, and Gangwon-do) in the 6th council; the percentages were $33.3 \%$ and $26.7 \%$, respectively. Considering the election results, a certain pattern of either a decreasing or increasing divided government was not observed, and a divided government appeared independently, regardless of the previous election.

Table 1. Unified and divided local government in Korea.

\begin{tabular}{cccccc}
\hline & Total & $\begin{array}{c}\text { Unified } \\
\text { Government }\end{array}$ & $\%$ & $\begin{array}{c}\text { Divided } \\
\text { Government }\end{array}$ & $\%$ \\
\hline $\begin{array}{c}\text { 4th } \\
(2006-2010)\end{array}$ & $15(100 \%)$ & 15 & 100 & 0 & 0 \\
\hline $\begin{array}{c}5 \text { th } \\
(2010-2014)\end{array}$ & $15(100 \%)$ & 10 & 66.7 & 5 & 33.3 \\
\hline $\begin{array}{c}\text { 6th } \\
(2014-2018)\end{array}$ & $15(100 \%)$ & 11 & 73.3 & 4 & 26.7 \\
\hline
\end{tabular}

Source: Reconstruction of data from the National Election Commission's historical election statistics (http: / / www.nec.go.kr accessed on 10 December 2021).

For analysis, whether the composition of the local government was unified or dividedthat is, whether the majority party in the local council is the same as the party to which the mayor or governor belongs-was used as a dummy variable. If the party to which the mayor or governor belongs and the parliamentary majority was the same, it was set to 0 for a unified government and 1 for a divided government. In this manner, how the competition structure that occurs according to the power distribution between the local council and mayor or governor affects the legislative performance of the councils could be investigated. We used three variables for the composition of party competition in the council: first, the seat share of the first party in the local council; second, the difference in seat share between the first and second parties in the local council; and, finally, the concentration ratio of the parties in the local council. For the seat share of the first party in the local council, the ratio of members of the party with the most seats in the local council was used as is. The seat share of the first party in the local council was the same as that of the party belonging to the mayor or governor in the case of a unified government but had a different value in the case of a divided government. The difference in seat share between the first and second parties was also calculated as the difference in seat share between the first and second parties in the local council. In a local council where the influence of a strong regional party would be greater, the seat share of the first party would appear higher and the difference in seat rate with the competing second party would appear larger. The concentration ratio of political parties in the local councils was calculated using the Hirschman-Herfindahl index (HHI), which evaluates the degree of competition in a market by measuring the degree of concentration of specific actors in the industry. The HHI is calculated by arranging companies from the largest to the smallest in sales, calculating the market share of each of the top 50 companies as a percentage, and summing the squares of these shares. The larger the value, the higher the concentration of the market. Resulting values of less than 1000, between 1000 and 1800, and above 1800 are classified as a "competitive market", a "moderately concentrated market", and a "very concentrated market", respectively. Based on the calculation method, the degree of party competition in the local council was indexed by squaring the seat shares of all parties entering parliament and adding them together. It should be noted that, based on the HHI standard, all metropolitan councils in Korea 
that were the subject of research analysis were classified as highly concentrated markets. Therefore, in the current study, the higher the index, the higher the party concentration and the lower the overall party competition.

The list of variables and their values are summarized in Table 2.

Table 2. Variable list and variable values.

\begin{tabular}{|c|c|c|}
\hline & Variable & Variable Value \\
\hline \multirow{4}{*}{ Independent variable } & Unified/Divided government & Unified government: 0, Divided government: 1 \\
\hline & Seat share of the first party in the local council & $\begin{array}{l}\text { (The number of seats for the first party in the local } \\
\text { council/number of seats) } \times 100\end{array}$ \\
\hline & $\begin{array}{l}\text { Difference in seat share between the 1st and 2nd } \\
\text { parties in the local council }\end{array}$ & $\begin{array}{l}\text { (The number of seats in the first party in the local } \\
\text { council-the number of seats in the second party } \\
\text { in the local council/number of seats) } \times 100\end{array}$ \\
\hline & $\begin{array}{l}\text { Concentration ratio of political parties in the local } \\
\text { councils }\end{array}$ & $\begin{array}{l}\text { The sum of the squares of the share of seats of the } \\
\text { parties in the local council } \\
((1 \text { st party seat share squared })+(2 \text { nd party seat } \\
\text { share squared })+(3 \text { rd party seat share squared })+ \\
\text { (4th party seat share squared }) . . \text { ) }\end{array}$ \\
\hline \multirow{2}{*}{ Dependent variable } & Proposal rate of the local council & $\begin{array}{l}\text { (The number of bills proposed by local } \\
\text { council/total number of bills proposed) } \times 100\end{array}$ \\
\hline & Approval rate of local council & $\begin{array}{l}\text { (The number of bills approved by local } \\
\text { council/total number of bills approved) } \times 100\end{array}$ \\
\hline
\end{tabular}

\subsection{Methodology}

Panel data combine time series data and cross-sectional data into one group while recording the phenomena or characteristics of several objects for a series of observation points. Analysis using panel data can reduce errors in the model setting by reflecting the unique characteristics of particular individuals in a model. In addition, complex phenomena, such as economies of scale and political environment, can be more rigorously analyzed through panel data analysis (Gujarati 2003).

In the current study, we used panel data for 12 years from the 4 th to 6 th terms of local councils, and the time series had a characteristic $(\mathrm{N}>\mathrm{T})$ that is smaller than the number of cross-sections. First-order regression analysis was performed with pooled OLS by considering the characteristics of the data; this was followed by the Breusch-Pagan test and the Woodridge statistical test. Afterwards, panel analysis was performed using the FGLS model, which estimates under the assumption that heteroscedasticity and autocorrelation exist. STATA was used as an analysis tool.

\section{Results}

Although the party system in Korea is a strong two-party system, it is a party system in which a third party (which is significant in election results) often exists, depending on the region and period. At the level of local elections, regional rifts are still strongly expressed, save for metropolitan areas and some regions. Accordingly, it can be said that the influence of the two large parties at the local council level is much greater than that of central politics. Compared to a case where the first and second parties are in a tight power struggle in the local council, most of the dominant party occupies the position of the first party, and the seat share of the second party - as well as of the third and fourth parties - is very low. In fact, the maximum case is that there are up to four parliamentary parties that have entered the local council, and out of the 45 metropolitan councils analyzed, only 23 were found to have a third party. The data, including basic information related to the internal and external party competition structure of local councils, are shown in Table 3. 
Table 3. Basic data for analysis.

\begin{tabular}{ccccc}
\hline Variable & Minimum & Maximum & Average & Standard Deviation \\
\hline $\begin{array}{c}\text { Seat share of the first party in the local council } \\
\begin{array}{c}\text { Difference in seat share between the first and second } \\
\text { parties in the local council }\end{array}\end{array}$ & 52.4 & 97.0 & 81.232 & 13.9136 \\
\hline $\begin{array}{c}\text { Concentration ratio of political parties in local councils } \\
\text { Proposal rate }\end{array}$ & 3854.9 & 94.4 & 67.614 & 26.2078 \\
\hline Approval rate & 17.2 & 86.2 & 43.097 & 1718.1606 \\
\hline
\end{tabular}

Among the 15 local councils formed through three local elections over the past 12 years, a divided government was found to be in 9 out of a total of 45 councils. In addition, the party concentration index had a maximum value of 9412 , a minimum value of 3854 , and an average of 7148 , indicating that the overall party concentration was very high.

Table 4 summarizes the results of the panel data analysis of the effects of party competition on the legislative productivity of local councils. Model I is the result of the regression analysis with the proposal rate as the dependent variable, and Model II is the result of regression analysis with the approval rate as the dependent variable.

Table 4. Analysis results ${ }^{1}{ }^{2}$.

\begin{tabular}{|c|c|c|c|}
\hline Variables & Model & $\begin{array}{c}\text { Model I } \\
\text { (Proposal Rate) }\end{array}$ & $\begin{array}{c}\text { Model II } \\
\text { (Approval Rate) }\end{array}$ \\
\hline & Unified/divided government & $\begin{array}{l}21.645 * \\
(11.282) \\
\end{array}$ & $\begin{array}{c}9.507 \\
(6.025) \\
\end{array}$ \\
\hline & Seat share of the first party in the local council & $\begin{array}{l}3.751 * * \\
(1.612)\end{array}$ & $\begin{array}{l}1.941^{* *} \\
(0.895)\end{array}$ \\
\hline & $\begin{array}{l}\text { Difference in seat share between the first and } \\
\text { second parties in the local council }\end{array}$ & $\begin{array}{l}-0.842 * \\
(0.457)\end{array}$ & $\begin{array}{l}-0.244 \\
(0.259)\end{array}$ \\
\hline & $\begin{array}{l}\text { Concentration ratio of political parties in the } \\
\text { local councils }\end{array}$ & $\begin{array}{c}-0.021^{* *} \\
(0.008)\end{array}$ & $\begin{array}{c}-0.0148^{* * *} \\
(0.004)\end{array}$ \\
\hline & Constant term & $\begin{array}{l}-82.678 \\
(57.216)\end{array}$ & $\begin{array}{l}-7141.906^{* * *} \\
(758.079)\end{array}$ \\
\hline & Wald $\chi^{2}$ & $10.23 *$ & $14.86^{* *}$ \\
\hline & Observed value & 45 & 45 \\
\hline & Group number & 15 & 15 \\
\hline
\end{tabular}

Because the legislative activities of 15 local councils in Korea were analyzed for 12 years, panel data for a total of 45 councils were constructed and analyzed. In Korea, presidential elections, parliamentary elections, and local elections are held at different times. The legislative activities of local councilors are greatly influenced by elections on a national scale, and each region receives various impacts. Therefore, rather than utilizing the annual proposal rate and the annual approval rate, the best way to compare an entire local council is to analyze the four-year term of local council members in units of analysis. Although the total number of observations in this study was small at 45 , the time range of the analysis was total of 12 years, which was a sufficient period to consider the specifics of Korean politics and to draw valid conclusions.

It was found that the proposal rate of local councils significantly increases when a divided government, rather than a unified government, is formed. This result can be interpreted as a positive effect on legislative productivity because there is a greater incentive 
to try to more proactively secure parliamentary representation and democracy toward the mayor or governor under the divided government.

Second, if the seat share of the first party in the local council increases, both the proposal and approval rates of the council increase. This result shows that the majority party plays an active role in legislation during the legislative, deliberation, and processing stages. As the power of the majority party increases, the incentives for responsible party politics increase and productive local council operation becomes possible through cooperative politics among the members of the council.

Third, as the difference in seat share between the first and second parties increases, the proposal rate of local councils tends to be negatively affected. When the first and second parties are in an appropriate competitive relationship, they can have a positive effect on actual legislative performance, but the overwhelming dominance of the first party in the council can be interpreted as reducing the incentives to compete.

Fourth, the higher the party concentration index in the local council, the lower both the proposal and approval rates of the council tend to be. The party concentration index of local councils is an index of party competition that utilizes all seats in the parliamentary party. It is an indicator of the influence of the minor political parties in local council that more accurately measures the influence of large two parties than whether it is a unified or divided government. The reason why this indicator has a very weak but negative effect on the relative legislative productivity of local councils involves the legislative activities of the minority party. The party concentration index increases when the minority party's seat share is relatively low, and the index decreases when the minority party's seat share increases. In other words, there is an inverse relationship in that the lower the seat share of the minority entering the council, the higher the party concentration. Minority party members show different strategies and behaviors depending on whether they can have a meaningful influence on legislative activities. If it is possible to propose and pass a proposal through their own legislative capacity, they can choose a strategy to carry out active legislative activities. However, if this is not the case, they can focus more on checking the ruling party than on their own legislative activities. In other words, members of the minority party in local councils with a high party concentration act as a kind of checkpoint or veto player in both the initiation process and the deliberation and approval process, here by actively participating in the entire legislative process as a check against the ruling party of the local government. Therefore, in the case of a local council with a high party concentration, the legislative productivity of the parliament is negatively affected by the check activities of minority parties. Conversely, in the case of a local council with a low party concentration, the legislative productivity of the parliament weakly increases.

The fact that the relative legislative productivity indicators of local councils with respect to the mayor/governor appear in different directions and intensities, here depending on the strength and weakness of the party competition structure, does not mean that the local councils are engrossed in each party competition structure and show fixed legislative behavior. Rather, it shows that they try to exert political dynamism in any situation.

The form of government, whether unified or divided, is only a constraint, and it is the people who operate the system. There are many cases in which a unified government is likely to be formed before and after because of the existence of strong local political parties. However, it cannot and should not be predicted that the legislative productivity of a local council will be low. Even in the same divided and unified governments, the results may differ depending on by whom and how the operation is conducted. Accordingly, the active competition of parties is necessary for the success of local autonomy, where checks and balances work well.

\section{Conclusions}

Korea is a country in which the power of the executive is relatively strong compared to that of parliament, which is a problem faced by many late democracies. This phenomenon is more pronounced at the local level. Korea is a society in which more than $50 \%$ of the 
total population and industry are concentrated around Seoul, which accounts for only $12 \%$ of the land area. Korean politics is also a vortex society, in which all elements rush toward central power and are synergized (Henderson 1968). Society is becoming more complex, and each region faces its own unique challenges. It is no longer possible to solve all problems with the Seoul-oriented thinking of Korean society. For the local autonomy system to work effectively, the role of efficient and productive local councils that can check local government is essential. At the center of this, there should be active competition from democratic parties.

In the current study, panel data analysis was conducted for 15 local councils to examine the effects of party competition structures inside and outside local councils on the relative legislative productivity of the local council to the mayor or governor. It was found that the political structure of divided governments at the local level does not necessarily lead to a decrease in legislative productivity. In addition, both the form of government and the competitive structure of the political parties within the local councils influence the legislative initiative of the local councils. The most important thing for productive local council operations is establishing a cooperative partnership between the mayor or governor and the local council. For this, it is necessary for the mayor or governor to pursue a cooperative relationship that respects the autonomy of the ruling party and to maintain competition and a cooperative relationship with the opposing party. Furthermore, the local councils must to acquire legislative initiative by further increasing the power of the legislative and improving the quality of legislation through internal competition. Additionally, for local councils to acquire and maintain legislative initiative over the executive, compromise through competition and cooperation between political parties is necessary.

In addition, the following policy suggestions can be derived based on the research results: The political competition structure surrounding parliament is a political and environmental factor of a parliament that has already begun its term because the political party competition structure is determined by election results. However, the results of actions performed under irreplaceable conditions are not predetermined. Therefore, various institutional supplements can be considered as a way to increase legislative productivity under certain constraints. Because of its authoritarian experience and path dependency, Korea has prioritized the executive branch over legislative branch, and human and material resources and powers have concentrated on the mayor or governor. As a result, the institutional basis for supporting the parliamentary activities of local councils is very weak. Therefore, it is necessary to strengthen the parliamentary support organization and increase the accompanying financial support by reinforcing the staff of the parliamentary secretariat, especially policy support professionals. Laws and systems should be reorganized in the direction of expanding the expertise and independence of local councils so that the mayor or governor and local councils can achieve checks and balances in both the legislative field and the entire local autonomy.

The present study was limited in that we could not analyze the level of party competition structure more strictly, and we did not examine the effect on the qualitative aspects of legislation. In the future, to overcome these limitations, it will be necessary to examine the deliberation process of a bill and the mayor or governor's request for reconsideration in more depth while also considering the effects of various party competition structures on the qualitative aspect of the legislation. Furthermore, it would be helpful to explore the effect of a broad party competition structure, including election competition for the formation of local councils, on the legislative productivity of individual local councils.

Author Contributions: Conceptualization, Y.K.; Data curation, S.E.J.; Methodology, S.E.J.; Writingoriginal draft, S.E.J.; Writing-review \& editing, Y.K. All authors have read and agreed to the published version of the manuscript.

Funding: This paper was supported by the KU Research Professor Program of Konkuk University.

Institutional Review Board Statement: Not applicable. 
Informed Consent Statement: Not applicable.

Conflicts of Interest: The authors declare no conflict of interest.

\section{Notes}

1 The variation inflation factor (VIF) value was measured to identify the problem of multicollinearity that may exist between independent variables. The average VIF value was 4.35, and there no variables has values exceeding 10 , so it was judged that there was no multicollinearity effect among the independent variables (VIF values for each independent variable: 1.16, 7.97, 3.31, and 4.94).

2 Number of observations $=45$; number of groups $=15$; time periods $=3$.

\section{References}

Azlansyah, Sultan Arief, Retno Sunu Astuti, and Budi Puspo Priyadi. 2020. Divided government and its impact on the performance of legislation in the Indonesian province of Aceh. JPPUMA: Jurnal Ilmu Pemerintahan dan Sosial Politik UMA (Journal of Governance and Political Social UMA) 8: 28-36. [CrossRef]

Binder, Sarah A. 2003. Stalemate: Causes and Consequences of Legislative Gridlock. Washington: Brookings Institution.

Cho, Sung-dai. 2003. Party nomination system in local elections: Regionalism, party competition, and productivity of the local assembly. 21st Century Political Science Review 13: 259-74. (In Korean).

Cox, Gary W., and William C. Terry. 2008. Legislative productivity in the 93rd-105th congresses. Legislative Studies Quarterly 33: 603-18. [CrossRef]

Edwards, George C., III, Andrew Barrett, and Jeffrey Peake. 1997. The legislative impact of divided government. American Journal of Political Science 41: 545-63.

Ellickson, Mark C. 1992. Pathways to legislative success: A path analytic study of the Missouri house of representatives. Legislative Studies Quarterly 17: 285-302. [CrossRef]

Fenno, Richard F. 1973. Congressmen in Committees. Cambridge: Scott Foresman \& Co. Little Brown, vol. 6.

Fiorina, Morris P. 1996. Divided Government. Boston: Allyn \& Bacon.

Gujarati, Damodar N. 2003. Basic Econometrics, 4th ed. New York: McGraw-Hill.

Henderson, Gregory. 1968. Korea, the Politics of the Vortex. Cambridge: Harvard University Press.

Jeong, Myung-Eun, and Jong-Soo Lee. 2008. Political party effect on local councils' activities. Journal of the Korean Urban Management Association 21: 25-28. (In Korean).

Jones, Charles O. 2005. The Presidency in a Separated System. Washington, DC: Brookings Institution Press.

Kelly, Sean Q. 1993. Divided we govern? A reassessment. Polity 25: 475-84. [CrossRef]

Kim, Soon-eun. 1997. Features and performances of local councils at the upper-tier local government established in 1995. Journal of Local Government Studies 9: 49-71. (In Korean).

Kirkland, Patricia A., and Justin H. Phillips. 2018. Is divided government a cause of legislative delay? Quarterly Journal of Political Science 13: 173-206. [CrossRef]

Lim, Heon-man. 2000. A study on the effect of political party composition on local government activities. Korean Public Administration Review 34: 193-212. (In Korean).

Matthews, Donald R. 1960. United States Senators and Their World. Chapel Hill: University of North Carolina Press.

Mayhew, David. 1991. Divided We Govern. New Haven: Yale University Press.

Mayhew, David. 2005. Divided We Govern: Party Control, Lawmaking and Investigations, 1946-2002. New Haven: Yale University Press.

McCubbins, Mathew Daniel, and Terry Sullivan, eds. 1987. Congress: Structure and Policy. New York: CUP Archive.

Olson, David M., and Cynthia T. Nonidez. 1972. Measures of legislative performance in the US House of Representatives. Midwest Journal of Political Science 16: 269-77. [CrossRef]

Park, Jae-yong. 2010. Analysis of Factors Affecting Local Legislative Activities: Focusing on Local Government Party Factors. Doctoral dissertation, Kookmin University, Seoul, Korea. (In Korean).

Park, Soon-jong, and Byeong-dae Choi. 2016. Divided government and the efficiency of legislation: The cases of Seoul Metropolitan City and Gyeonggi Province. Korean Public Administration Review 50: 161-88. (In Korean). [CrossRef]

Rogers, James R. 2005. The impact of divided government on legislative production. Public Choice 123: 217-33. [CrossRef]

Schiller, Wendy J. 1995. Senators as political entrepreneurs: Using bill sponsorship to shape legislative agendas. American Journal of Political Science 39: 186-203. [CrossRef]

Sundquist, James L. 1988. Needed: A political theory for the new era of coalition government in the United States. Political Science Quarterly 103: 613-35. [CrossRef]

Thomas, Nicholas. 1995. Positive Theories of Congressional Institutions. Ann Arbor: University of Michigan Press.

Volden, Craig, and Alan E. Wiseman. 2014. Legislative Effectiveness in the United States Congress: The Lawmakers. Cambridge: Cambridge University Press. 
Wu, Chung-li, and Chi Huang. 2007. Divided government in Taiwan's local politics: Public evaluations of city/county government performance. Party Politics 13: 741-60. [CrossRef]

$\mathrm{Wu}$, Chung-li. 2009. Semi-presidentialism and divided government in Taiwan: Public perceptions of government performance. Issue $\mathcal{E}$ Studies 45: 1-34. 